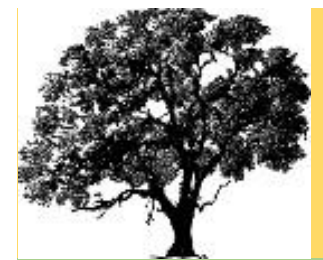

\title{
Seven years of arboreal pollen monitoring in the İğneada waterlogged forests (NW Turkey)
}

\author{
Nurgül KARLIOĞLU KILIÇ
}

\author{
Istanbul University-Cerrahpaşa, Faculty of Forestry, Department of Forest Botany, 34473, Bahçeköy, Istanbul, Turkey. \\ Corresponding author: nurgulk@istanbul.edu.tr
}

\begin{abstract}
This study was carried out in the İğneada Waterlogged Forests (Kırklareli) located downhill of Istranca mountains at 20 $\mathrm{km}$ distance to Bulgaria border line and had a shore to Black Sea. These forests have different vegetation types such as waterlogged forest, peat, bog and sand dunes plant communities, sand zone and wetlands. The main arboreal species of these forests are Acer campestre, Acer trautvetteri, Alnus glutinosa, Carpinus betulus, Carpinus orientalis, Fraxinus angustifolia, Fraxinus ornus, Juglans regia, Quercus cerris, Quercus frainetto, Quercus petraea, Quercus robur, Ulmus leavis and Ulmus minor. Pollen monitoring results were obtained from six different sampling sites in the waterlogged forests around Mert and Saka Lake. The purpose of this study is to determine the modern pollen distribution of these forests and to create a basic calibration scheme for the fossil pollen studies. For this purpose, seven years of modern pollen distribution was monitored between September 2009 and 2016 using Tauber pollen traps which were placed at 6 different points in this study area. These traps were changed once a year in the field and transferred to the Palynology Laboratory of Istanbul University-Cerrahpaşa. The protocol of European Pollen Monitoring Programme (EPMP) was followed in the laboratory methodology. The majority of the pollen influx obtained from the Tauber pollen traps in the İğneada Waterlogged forests belongs to Fraxinus and Carpinus from 2009 to 2016. As a result of this study, the annual arboreal pollen influxes of Fraxinus, Carpinus, Quercus, Acer, Corylus, Ulmus, Hedera helix and Alnus was higher respectively in the years of 2009-2016. Seven-year pollen influx data of these pollen traps reflects the current vegetation.
\end{abstract}

Keywords: European Pollen Monitoring Programme, Tauber pollen trap, İğneada.

\section{Özet}

Bu çalışma, Bulgaristan sınırına 20 km uzaklıkta Istranca Dağları'nın aşağı yamaçlarında bulunan ve Karadeniz'e kıyısı olan İğneada Longoz Ormanları'nda gerçekleştirilmiştir. Bu ormanlar; subasar orman, turba, bataklık ve kumul bitki toplulukları, kumsal ve sulak alanlar gibi farklı vejetasyon tiplerine sahiptir. $\mathrm{Bu}$ ormanların önemli odunsu taksonları Acer campestre, Acer trautvetteri, Alnus glutinosa, Carpinus betulus, Carpinus orientalis, Fraxinus angustifolia, Fraxinus ornus, Juglans regia, Quercus cerris, Quercus frainetto, Quercus petraea, Quercus robur, Ulmus leavis ve Ulmus minor'dür. Polen izleme sonuçları, Mert ve Saka gölü etrafında bulunan subasar ormanlarının içindeki altı farklı örnek alanından elde edilmiştir. Bu çalışmanın amacı, bu ormanların güncel polen dağılımını belirlemek ve fosil polen çalışmaları için temel bir kalibrasyon şeması oluşturmaktır. Bu amaçla, çalışma alanında 6 farklı noktaya yerleştirilen Tauber polen tuzakları kullanılarak Eylül 2009 ve 2016 yılları arasında yedi yıllık güncel polen birikimi izlenmiştir. Bu tuzaklar yılda bir kez arazide değiştirildikten sonra İstanbul Üniversitesi-Cerrahpaşa Palinoloji Laboratuvarı'na getirilmiştir. Laboratuvar metodolojisinde Avrupa Polen İzleme Programı (European Pollen Monitoring Programme: EPMP) protokolü takip edilmiştir. İğneada Longoz Ormanlarındaki tuzaklardan 2009-2016 yılları arasında elde edilen polen yoğunluğunun çoğunluğu Fraxinus ve Carpinus'a aittir. Bu çalışmanın sonucu olarak, 2009-2016 yılları arasındaki yıllık odunsu bitki polen yoğunluğu sirasılla Fraxinus, Carpinus, Quercus, Acer, Corylus, Ulmus, Hedera helix ve Alnus'ta fazla çıkmıştır. Polen tuzaklarına ait 7 yıllık polen yoğunluğu verileri güncel vejetasyonu yansıtmaktadır.

Anahtar kelimeler: Avrupa Polen İzleme Programı, Tauber polen tuzağı, İğneada. 


\section{Introduction}

Monitoring the modern pollen influx for many years is very important in order to determine the paleovegetation and climate of Quaternary based on the fossil pollen studies. There is little knowledge about the distribution and sedimentation processes of the modern pollen grains and how they represent the current vegetation at the regional and local scale. In accordance with this purpose, European Pollen Monitoring Programme (EPMP) was established in 1996 and modern pollen-monitoring stations have been created in many European countries during the last 23 years. Pollen influx data has been obtained by monitoring the pollen accumulation at varying vegetation points by using Tauber pollen traps properly according to the protocol of EPMP (Hicks et al., 1996; Hicks, 2001; Van der Knaap et al., 2001; Pidek, 2004; Tonkov et al., 2001; Atanassova, 2007; Filipova-Marinova et al., 2007; Giesecke et al., 2010; Tonkov et al., 2016).

The modern palynological studies conducted in Turkey are mostly about pollen allergy, pollen analysis in the atmosphere and airborne pollen concentration. In these studies; Hirst Spore, Burkard and Lanzoni style traps were used at a certain height and a lot of pollen calendars belong to many provinces of Turkey were created with this method (Aytuğ et al., 1974; İnce and Pehlivan, 1990; Pehlivan and Bütev, 1994; İnceoğlu et al., 1994; Kaya and Aras, 2004; Biçakçı, 2006; Öneş et al., 2008; Erkan et al., 2011; Bıçakçı and Tosunoğlu, 2019).

Among these studies, the first pollen monitoring study in Turkey was conducted as a doctorate thesis in the context of EPMP, which aims to find out the relationship between meteorological parameters and monthly pollen influx in Belgrad Forest and İğneada Longoz Forest between 2007 and 2009 (Karlığlu, 2011; Karlığlu and Akkemik 2012, Karlığlu et al. 2014, Karlıŏlu et al. 2015). EPMP studies have been continued in different regions of Turkey in accordance with this protocol (Şenkul et al. 2018a, Şenkul et al. 2018b; Şenkul et al. 2018c; Karlığlu Kılıç et al., 2019; Şenkul and Karlığlu Kılıç, 2019).

The aim of this study is to investigate the seven years of arboreal pollen monitoring in the different sample areas of İgneada Waterlogged Forests in accordance with the EPMPP. This study will be a basic calibration scheme in order to better interpret the quantitative reconstructions of previous fossil pollen diagrams.

\section{Material and Methods \\ Study Site}

İğneada Waterlogged (Longoz) Forests belong to Kırklareli-Demirköy province locates downhill of Istranca mountains at $20 \mathrm{~km}$ distance to Bulgaria border line and has shore to Black Sea. According to Davis' (19651985) grid system locates in A1 (E) square. The altitudinal profile of İgneada waterlogged forests is between 0-20 m (Fig.1). These forests have different vegetation types such as waterlogged forest, peat, bog and sand dunes plant communities and sandy meadows at river side banks, sand zone and wetlands. They are accepted as one of the 122 Important Plant Areas of Turkey (Özhatay et al 2005). The dominant arboreal plant species in the area are Acer campestre L. (Common Maple), Alnus glutinosa (L.) Gaertn. (Common Alder), Fraxinus angustifolia Vahl. (Narrow-leafed Ash), Quercus cerris L. (Turkish Oak), Quercus frainetto Ten. (Hungarian Oak), Quercus robur L. (Pedunculate Oak), Quercus petraea (Mattuschka) Liebl. (Sessile Oak), Fagus orientalis Lipsky. (Oriental Beech), Carpinus betulus L. (Common Hornbeam), Carpinus orientalis (Hornbeam), Ulmus minor Miller (Common Elm) and Ulmus leavis Pall. (European White Elm). Fraxinus angustifolia is the most widespread tree species in the İğneada Waterlogged Forests. Another tree species, which has a wide spread like ash, is common maple. There is a rich ecological diversity in this forest, which has a total area of approximately 1600 ha (Kavgac1, 2007; Karlığlu, 2011). 


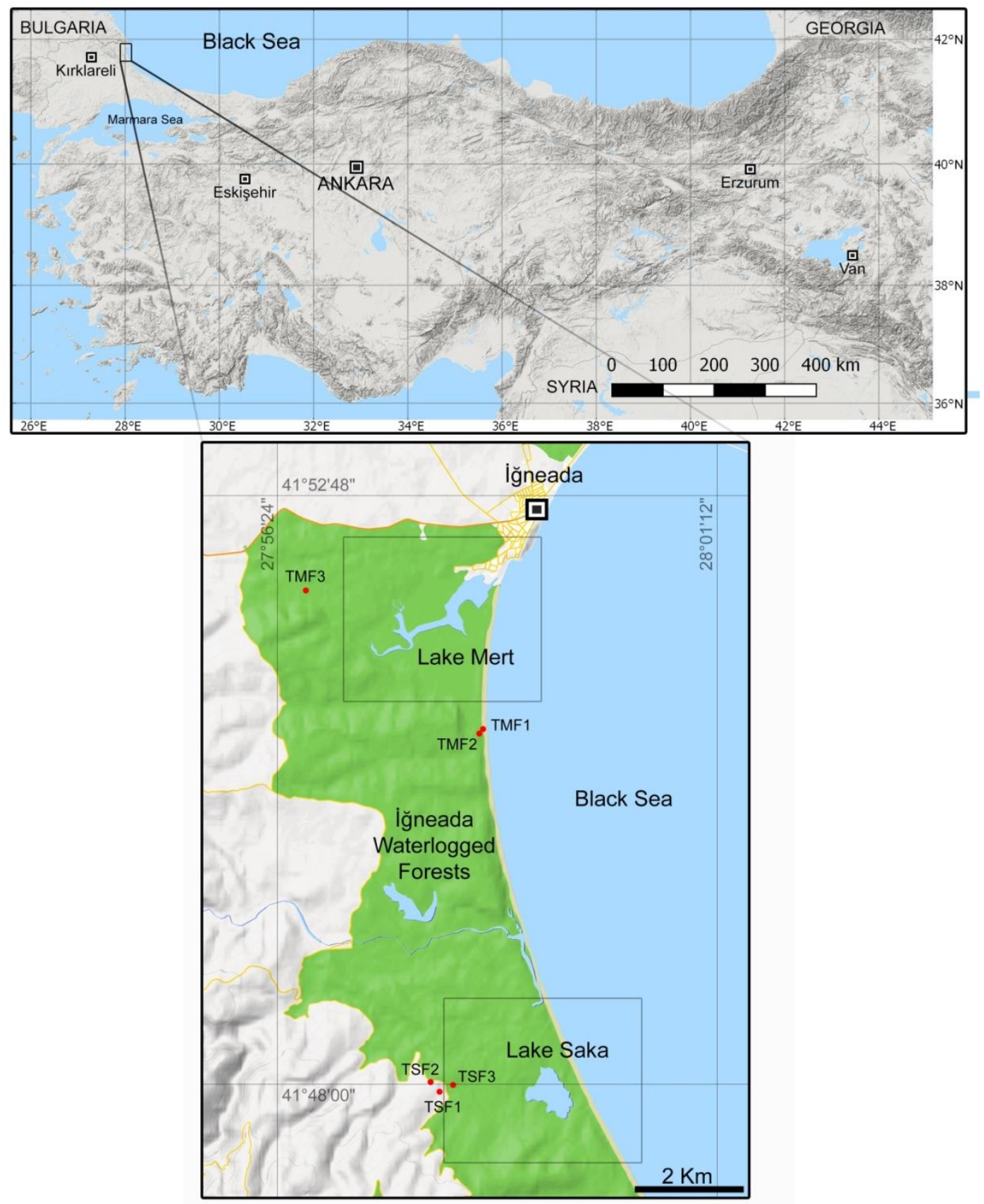

Figure 1. Location map of the study area and position of the Tauber pollen traps in the sample areas ("red circles" show the location of the pollen traps in the field)

\section{Modern Pollen Analysis}

Tauber pollen traps were placed in six sample areas (TMF1, TMF2, TMF3, TSF1, TSF2 and TSF3) of İgneada Waterlogged Forests where the vegetation changed in 2007 for the first time and these traps were changed monthly between September 2007 and 2009 as a doctorate thesis (Figure 1). Then, these same traps were changed annually between 2009 and 2016. Each Tauber pollen trap (Tauber, 1974) was brought from the field to the Palynology Laboratory of Istanbul University-Cerrahpaşa. For every 1-year period, the mixture in the each trap was used for the modern pollen analysis according to the protocol of EPMP (Hicks et al., 1996). Every mixture in each trap was filtered by using a sieve of $250 \mathrm{~m} \mu$ and removed from animal and plant remains (Hicks et al., 1996). Two Lycopodium spore tablets (Stockmarr 1971) were added into this mixture, 
and this mixture was centrifuged (10 minutes at 3000-3500 rpm) until reaching the sediment. Then $10 \mathrm{ml}$ acetolysis mixture was added to the resulting sediment. After acetolysis process, pollen slides were prepared by adding $2 \mathrm{ml}$ of glycerin. Pollen grains and Lycopodium spores were counted by Leica DM 750 light microscope with $\times 40$ and $\times 100$ immersion objective and x10 ocular. Reference slides and illustrated pollen keys were used for the identification of pollen grains (Aytuğ, 1967; Aytuğ et al., 1971; Wodehouse, 1935; Erdtman, 1952; 1957; Hyde and Adams, 1958; Faegri and Iversen, 1964; Moore et al., 1991; Hesse et al., 2009; Iwanami et al., 1988). Also, arboreal plants around the traps $(0-10.5 \mathrm{~m})$ were identified using the vegetation ring.

\section{Results}

Annual pollen influxes ( $\mathrm{cm}^{2} /$ year) of the arboreal plants around the traps have been determined between 2009 and 2016 in the six sample areas of İgneada Waterlogged Forests (Figure 2; Figure 3). Also, the seven years of arboreal pollen monitoring diagram was drawn in TILIA (Figure 4).

\section{Annual Pollen Influx in the Mert Lake Waterlogged Forest between 2009-2016}

The pollen trap in the open area (TMF1) was missing between 2009 and 2010 in the Mert Lake Waterlogged Forest. Carpinus and Fraxinus have the highest annual pollen influx $\left(\mathrm{cm}^{2} /\right.$ year) between 2009 and 2011 in TMF3 (in the Forest). The pollen trap in the forest area was missing from 2011 to 2012. Annual pollen influxes of Fraxinus, Carpinus and Quercus were higher in the forest area (TMF3) between 2011 and 2012. In the years of 2012-2013, the annual pollen influx of Carpinus, Fraxinus and Acer was higher in all sample areas of Mert Lake Waterlogged Forest. The pollen trap in the open area was missing between 2013 and 2014. Annual pollen influxes of Carpinus, Fraxinus, Corylus and Hedera helix were higher in the forest and at the forest edge in the years of 2013-2014. The pollen trap in TMF3 was missing from 2014 to 2016. Annual pollen influx was very low from 2014 to 2015. In this year, the highest annual pollen influxes belong to Fraxinus and Carpinus in TMF1 and TMF2. When the annual arboreal pollen influx in the years of 20152016 was examined, the pollen influxes of Ulmus, Fraxinus, Carpinus, Acer and Alnus were higher in TMF1 and TMF2. In 2016-2017, pollen influx of Ulmus was very high when it was compared with the other years (Figure 2; Figure 4).

\subsection{Annual Pollen Influx in the Saka Lake Waterlogged Forest between 2009-2016}

The pollen trap in the forest area (TSF3) was missing between 2009 and 2010 in the Saka Waterlogged Forests. Carpinus, Fraxinus and Quercus have the highest annual pollen influx (cm²/year) between 2009 and 2010 in TSF2 (forest edge) and in the open area (TSF1). The pollen traps in TSF1 and TSF2 were missing from 2010 to 2011. When the annual arboreal pollen influx in the years of 2010-2011 was examined in TSF3, the pollen influxes of Fraxinus, Corylus, Acer and Carpinus were higher in this sample area. The pollen trap in TSF2 was missing between 2011-2012. Annual pollen influxes of Carpinus, Fraxinus, Quercus and Corylus were higher in the forest area (TSF3) and open area (TSF1) from 2011 to 2012. All the traps were missing in the years of 2012-2013. The traps in TSF1 and TSF2 were also missing between 2013 and 2014. When the annual arboreal pollen influx in the years of 2013-2014 was examined in TSF3, the pollen influxes of Fraxinus, Corylus, Acer, Hedera helix and Quercus were higher in this sample area. In the years of 20142015, the pollen trap in TSF2 was missing. Annual pollen influxes of Fraxinus, Corylus, Carpinus Hedera helix and Alnus were higher in the forest area (TSF3) and open area (TSF1) from 2014 to 2015. The pollen trap in TSF2 was missing between 2015 and 2016 again. When the annual arboreal pollen influx in the years of 2015-2016 was examined, the pollen influxes of Corylus, Carpinus, Fraxinus, Quercus and Alnus were higher in TSF1 and TSF3. Total annual pollen influx in the years of 2015-2016 was very higher than the other years (Figure 3; Figure 4). 


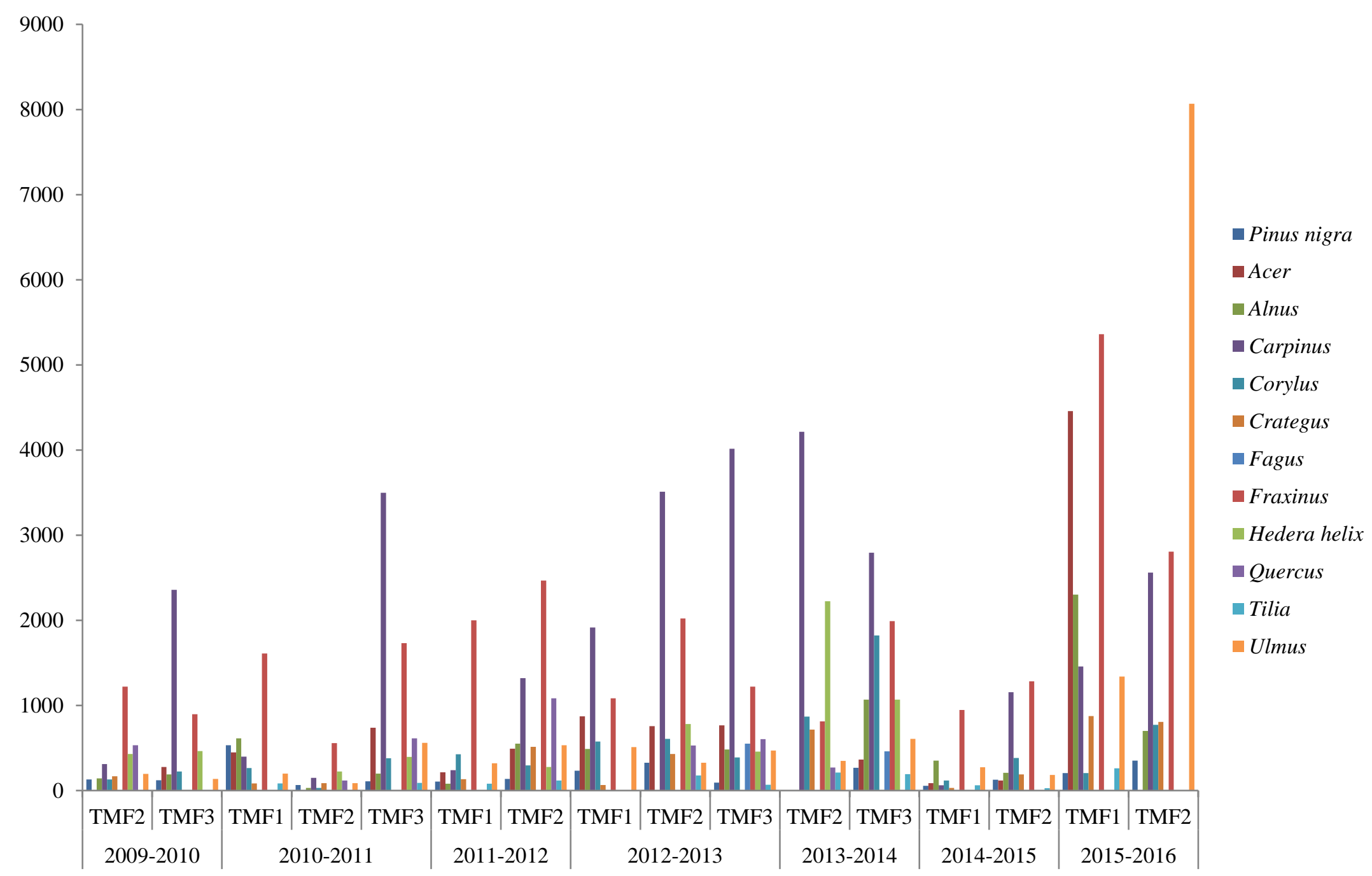

Figure 2. Annual pollen influx ( $\mathrm{cm}^{2} /$ year) of arboreal plants in Mert Lake Waterlogged Forest between 2009-2016.

$$
\text { (TMF1: Open area TMF2: Forest edge TMF3:In the Forest area) }
$$




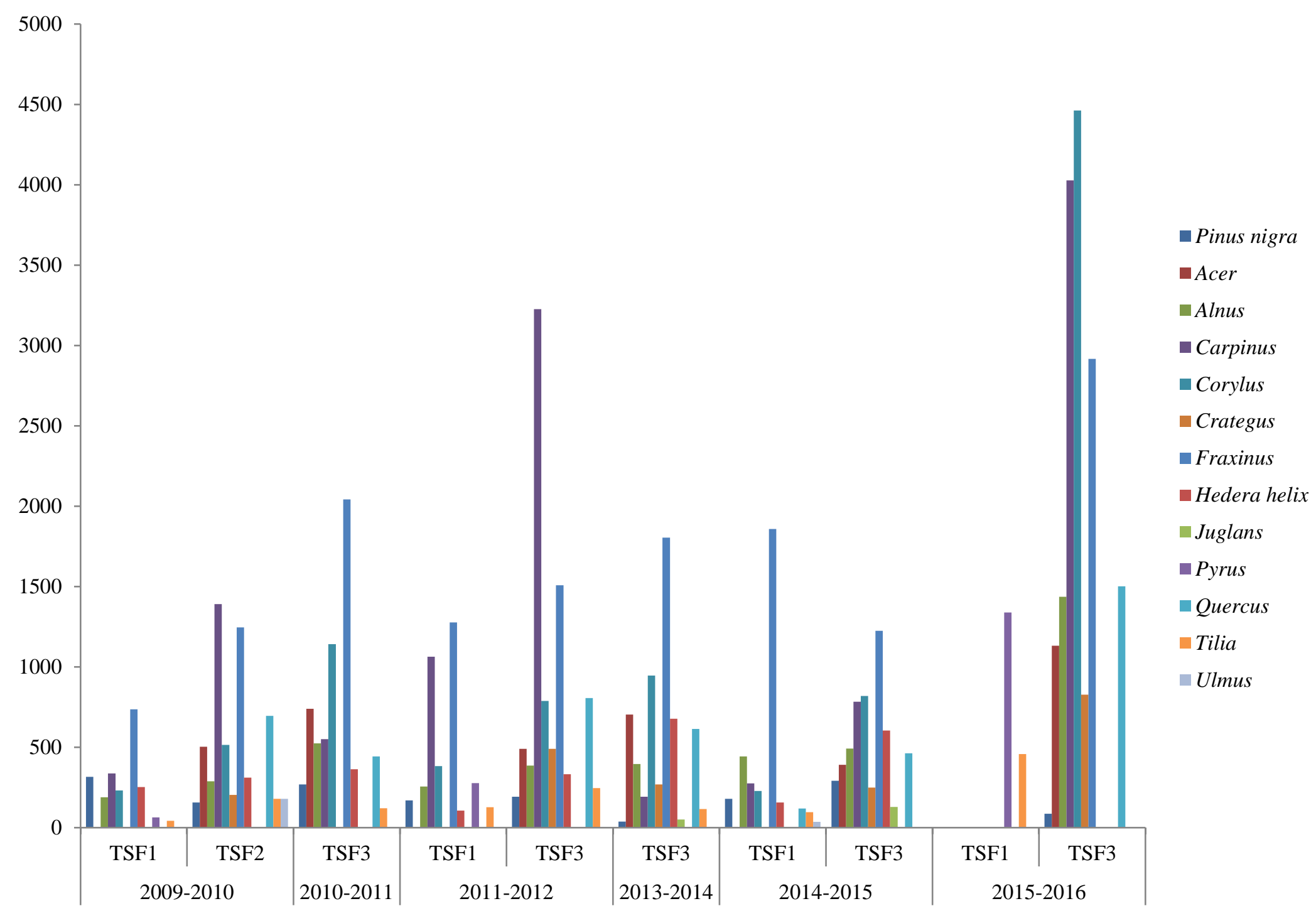

Figure 3. Annual pollen influx ( $\mathrm{cm}^{2} /$ year) of arboreal plants in Saka Lake Waterlogged Forest between 2009-2016.

$$
\text { (TSF1: Open area TSF2: Forest edge TSF3:In the Forest area) }
$$




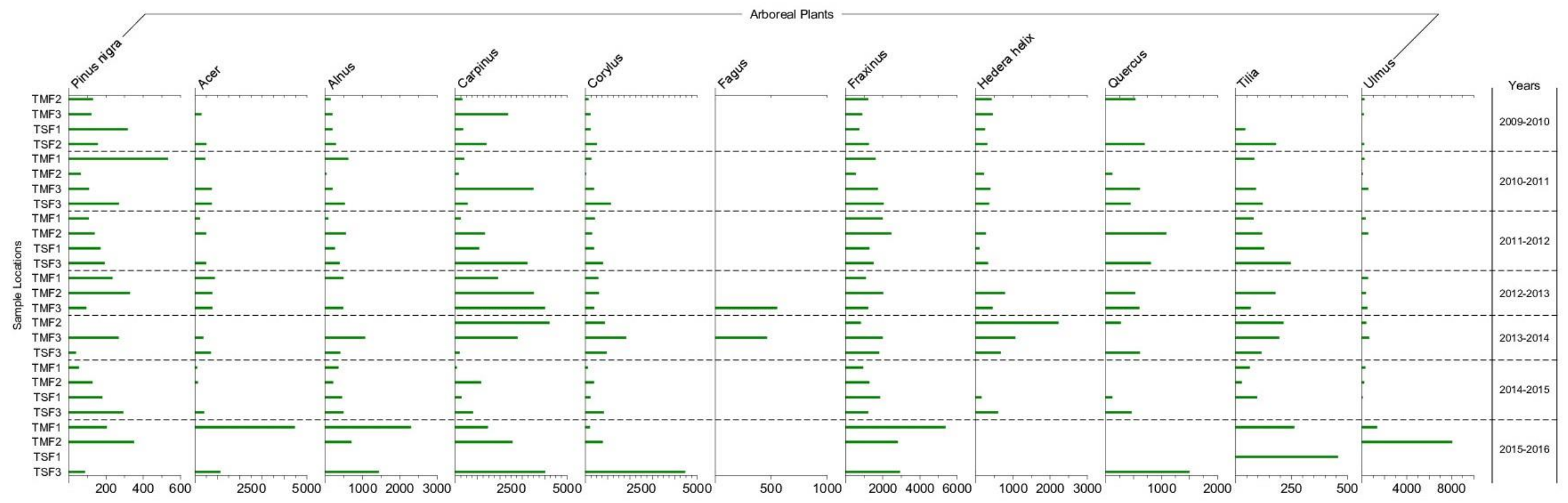

Figure 4. Seven years of arboreal pollen monitoring in İğneada Waterlogged Forests between 2009 and 2016. 


\section{The arboreal plant species around the Tauber pollen traps}

The identification of the arboreal plant species around the Tauber pollen traps is very important to show how far the pollen grains are transported in the sample areas. Therefore, all woody plant taxa around the pollen traps were listed in Table 1.

Table 1. The arboreal plant species around pollen traps surrounding circle with the radius $10.5 \mathrm{~m}$

TMF1 Acer campestre, Crataegus monogyna, Fraxinus angustifolia, Prunus x domestica,

Rubus sanctus, Ulmus minor.

TMF2 Acer campestre, Crataegus monogyna, Fraxinus angustifolia, Hedera helix, Prunus $x$ domestica, Rosa canina, Ruscus aculeatus, Smilax excelsa, Ulmus minor.

TMF3 Acer campestre, Carpinus betulus, Corylus avellana, Fagus orientalis, Fraxinus angustifolia, Hedera helix, Rubus sanctus, Ruscus aculeatus, Smilax excelsa, Sorbus torminalis, Tilia tomentosa.

TSF1 Fraxinus angustifolia, Pyrus elaeagnifolia, Rosa canina.

TSF2 Acer campestre, Crataegus monogyna, Fraxinus angustifolia, Hedera helix, Malus sylvestris, Quercus robur, Rosa canina, Ruscus aculeatus, Smilax excelsa.

TSF3 Acer campestre, Carpinus betulus, Cornus mas, Corylus avellana, Crataegus monogyna Fraxinus angustifolia, Hedera helix, Quercus robur, Ruscus aculeatus, Smilax excelsa.

\section{Discussion}

According to the results of pollen analysis in the pollen traps, the annual pollen influxes $\left(\mathrm{cm}^{2} / \mathrm{year}\right)$ of Fraxinus, Carpinus, Quercus, Acer, Corylus, Ulmus, Hedera helix and Alnus was higher respectively between 2009 and 2016 in the İğneada Waterlogged Forests. Total annual pollen influx between 2015 and 2016 was higher than the other years. Seven-year arboreal pollen influx data of pollen traps reflect the current vegetation in this forest. Karlıoglu and Akkemik (2012), Karlığlu et al. (2015), Şenkul et al. (2018a; 2018b), and Karlığlu Kılıç et al. (2019) found that annual pollen influx $\left(\mathrm{cm}^{2} / y e a r\right)$ is very related to the modern vegetation in the different regions of Turkey.

Pinus sp. does not exist in all sample areas of İgneada Waterlogged Forests, but it has pollen influx in the all traps. Pollen grains of Pinus have 2 air-filled bladders (sacci), and these air sacs increase surface area, but don't increase the pollen mass. Thereby, the pollen grains of Pinus can be easily transported to long distances by wind (Schwendemann et al., 2007; Szczepanek et al., 2017).

\section{REFERENCES}

Atanassova, J. (2007). Pollen deposition in moss polsters and pollen traps in the Central Stara Planina Mts. (2002-2005). Phytologia Balcanica. 13 (2): 223-228.

Aytuğ, B. (1967). Polen Morfolojisi ve Türkiye'nin Önemli Gymnospermleri Üzerinde Palinolojik Araştırmalar. Kutulmuş Matbaası, İstanbul.

Aytuğ, B., Aykut, S., Merev, N., Edis, G. (1971). İstanbul çevresi bitkilerinin polen atlası. İ.Ü. Orman Fakültesi Yayınları No:174, Kutulmuş Matbaası, İstanbul. 
Aytuğ, B., Aykut, S., Merev, N., Edis, G. (1974). Belgrad Ormanı'nın ve İstanbul çevresi bitkilerinin polinizasyon olayının tespiti ve değerlendirilmesi. TÜBİTAK Yayınları No:221.

Bıçakçı, A. (2006). Analysis of airborne pollen fall in Sakarya-Turkey. Biologia. 61(4): 531-549.

Biçakçı, A., Tosunoğlu, A. (2019). Allergenic Pollens in Turkey. Asthma Allergy Immunol. 17: 7-24.

Erdtman, G. (1952). Pollen Morphology and Plant Taxonomy- Angiosperms. The Chronica Botanica Company, Waltham, Mass., U.S.A.

Erdtman, G. (1957). Pollen and Spore Morphology / Plant Taxonomy - Gymnospermae, Pteridopyhta, Bryophyta. Stockholm.

Erkan, P., Bıçakc1, A., Aybeke, M., Malyer, H. (2011). Analysis of airborne pollen grains in Kırklareli. Turkish Journal of Botany. 35: 57-65.

Faegri, K., Iversen, J. (1964). Textbook of Pollen Analysis. II Edition, Munksgaard, Copenhagen, Denmark.

Filipova-Marinova, M., Bozilova, E., Hicks, S. (2007). Pollen monitoring of forest communities in the Strandzha Mts. Bulletin du Musee National de Varna. 41(56): 135-155.

Giesecke, T., Fontana, S.L., Van Der Knaap, W.O., Pardoe, H.S., Pidek, I.A. (2010). From early pollen trapping experiments to the Pollen Monitoring Programme. Vegetation History and Archaeobotany. 19 (4): 247-258.

Hesse, M., Zetter, R., Halbritter, H., Weber, M., Buchner, R., Frosch-Radivo, A., Ulrich, S. (2009). Pollen Terminology an illustrated handbook. Austria, Springer Wien New York.

Hicks, S. (2001). The use of annual arboreal pollen deposition values for delimiting tree-lines in the landscape and exploring models of pollen dispersal. Review of Palaeobotany and Palynology. 117: 1-29.

Hicks, S., Ammann, B., Latalowa, M., Pardoe, H., Tinsley, H. (1996). European Pollen Monitoring Programme: Project Description and Guidelines. University of Oulu, $28 \mathrm{pp}$.

Hyde, H. A., Adams, K. F. (1958). An Atlas of Airborne Pollen Grains. Macmillan Company, London.

Iwanami, Y., Sasakuma, T., Yamada, Y. (1988). Pollen: Illustrations and Scanning Electronmicrographs. KodonshaTokyo.

İnce, A., Pehlivan, S. (1990). Serik (Antalya) havasının allerjenik polenleri ile ilgili bir araştırma. Gazi Tıp Dergisi. 1: $35-40$.

İnceoğlu, Ö., Pınar, N.M., Şakıyan, N., Sorkun, K. (1994). Airborne pollen concentration in Ankara-Turkey 1990-1993. Grana. 33: 158-161.

Karlıoğlu, N. (2011). Istranca ve Belgrad Ormanlarında Güncel Polen Dağılımının İncelenmesi. (Doktora Tezi). İstanbul Üniversitesi Fen Bilimleri Enstitüsü.

Karlıoğlu, N., Akkemik, Ü. (2012). İ.Ü. Orman Fakültesi Araştırma Ormanı'nda Eylül 2007-Ağustos 2009 Dönemi Güncel Polen Dağlımı. Journal of the Faculty of Forestry, Istanbul University. 62 (2): 145-158.

Karlıoğlu, N., Caner, H., Akkemik, Ü. (2014). Modern pollen distribution at Iğneada waterlogged forests between the periods September 2007-August 2009. Eurasian Journal of Forest Science. 2 (2): 7-17.

Karlıoğlu, N., Caner, H., Akkemik, Ü., Köse, N., Kındap, T. (2015). Modern Pollen Monitoring of Native Trees in Belgrad Forest, Istanbul (Northwestern Turkey). Comptes rendus de I'Académie bulgare de Sciences. 68 (1): 39-48.

Karlıŏlu Kılıç, N., Şenkul, Ç., Memiş, T., Doğan, M. (2019). Salurtepe Dağı (Elmalı-Antalya) Ardı̧ Ormanında Güncel Polen Dağılımının İncelenmesi. Coğrafya Dergisi. 38: 11-22. 
Kavgacı, A. (2007). Demirköy-İğneada Longoz Ormanları ve Çevresinin Bitki Toplumları ve Kuruluş Özellikleri. Doktora Tezi, İ.Ü. Fen Bilimleri Enstitüsü, 215 s.

Kaya, Z., Aras, A. (2004). Airborne pollen calendar of Bartın-Turkey. Aerobiologia. 20 (1): 63-67.

Moore, P., Webb, J. A., Collinson, M. E. (1991). Pollen Analysis. 2nd Edition, Blackwell, Oxford, 216 pp.

Öneş, Ü., Sapan, N., Malyer, H., Güler, N., Bıçakçı, A., Tamay, Z., Tatlıdil, S. (2008). İstanbul İlinin Allerjik Polen Takvimi. TÜBITTAK SBAG Proje No:102S021.

Özhatay, N., Byfield, A., Atay, S. (2005). Türkiye’nin 122 Önemli Bitki Alanı, Doğal Hayatı Koruma Vakfı (WWF Türkiye) Yayını, İstanbul.

Pehlivan, S., Bütev, F. (1994). Aksaray ili atmosferindeki polenlerin araştırılması. Journal of the Institute of Science and Technology of Gazi University. 7: 143-151.

Pidek, I.A. (2004). Preliminary results of pollen trapping in the region of the Roztocze National Park (SE Poland). Annales Univ. M. Curie-Sklodowska sect. B. 49:143-159.

Stockmarr, J. (1971). Tablets with spores used in absolute pollen analysis. Pollen et Spores. 13: 615-621.

Schwendemann, A.B., Wang, G., Mertz, M.L., McWilliams, R.T., Thatcher, S.L., Osborn, J.M. (2007). Aerodynamics of saccate pollen and its implications for wind pollination. American Journal of Botany. 94 (8): 1371-81.

Szczepanek, K., Myszkowska, D., Worobiec, E., Piotrowicz, K., Ziemianin, M., Bielec-Bąkowska, Z. (2017). The longrange transport of Pinaceae pollen: an example in Kraków (southern Poland). Aerobiologia (Bologna). 33(1): 109-125. Şenkul, Ç., Karlığlu Kılıç, N., Kargı̊̆glu, M. (2018a). Teke Yarımadası Ormanlarında Güncel Polen Dağılımının ve Mikro İklim Koşullarının Belirlenmesi, TÜBİTAK Proje No: 214O249, Isparta.

Şenkul, Ç., Karlığlu Kılıç, N., Doğan, M., Eastwood, W.J. (2018b). Modern pollen distribution of the Teke Peninsula forests: The case of the Ördübek Highland. Eurasian Journal of Forest Science. 6(4):58-75.

Şenkul, Ç., Karlığlu Kılıç, N., Kargıoğlu, M., Kulakoğlu, F. (2018c). Kültepe (Kayseri) Çevresinin Fosil ve Güncel Polen Analizleri Işı̆̆ında Holosen Ortamsal Değişimi, TÜBİTAK Proje No: 114Y578, Isparta.

Şenkul, Ç., Karlığlu Kılıç, N. (2019). Modern Pollen Distribution of Çı̆̆lıkara Cedrus libani Forest (Southwest of Turkey). Comptes rendus de l'Académie bulgare des Sciences. 72 (6): 758-767.

Tauber, H. (1974). A static non-overload pollen collector. New Phytologist. 73: 359-369.

Tonkov, S., Hicks, S., Bozilova, E., Atanassova, J. (2001). Pollen monitoring in the Central Rila Mountains, Southwestern Bulgaria: case studies from pollen traps, surface samples for the period 1994-1999. Review of Palaeobotany and Palynology. 117: 167-182.

Tonkov, S., Bozilova, E., Pavlova, D., Raev, I. (2016). Long-term pollen monitoring experiments for the period 19942008 in the Rila Mountains, Bulgaria. Eurasian Journal of Forest Science. 4(1): 1-16.

Van Der Knaap, W.O., Van Leeuwen, J.F.N., Ammann, B. (2001). Seven years of annual pollen influx at the forest limit in the Swiss Alps studied by pollen traps: relations to vegetation and climate. Review of Palaeobotany \& Palynology. 117: $31-52$.

Wodehouse, R. P. (1935). Pollen Grains. Hafner Publishing Company, New York, 574 pp. 